\title{
Anhydrous Proton Conduction of Soy Protein
}

\author{
Masanori Yamada, ${ }^{1, *}$ Yuka Nagano ${ }^{1}$, and Tetsuya Yamada ${ }^{2}$ \\ ${ }^{1}$ Department of Chemistry, Faculty of Science, Okayama University of Science, Ridaicho, Kita-ku, \\ Okayama 700-0005, Japan \\ ${ }^{2}$ Research Faculty of Agriculture, Hokkaido University, Sapporo 060-8589, Japan \\ "E-mail: myamada@chem.ous.ac.jp
}

doi: $10.20964 / 2021.01 .74$

Received: 9 October 2020 / Accepted: 16 November 2020 / Published: 30 November 2020

\begin{abstract}
Water-soluble soy protein contains a large amount of acidic amino acids, such as glutamic and aspartic acids. Since these acidic amino acids possess the $-\mathrm{COOH}$ group in their side chain, the water soluble soy protein acts as an acidic polymer. Therefore, we prepared a composite material by the mixing of acidic protonated soy protein ( $\mathrm{SPH}$ ) and a basic heterocyclic molecule, such as imidazole ( $\mathrm{Im})$. The SPH-Im composite materials showed a thermal stability at $\leq 130{ }^{\circ} \mathrm{C}$ by the acid-base interaction between the acidic $-\mathrm{COOH}$ group, related to the side chain of the acidic amino acids, and basic Im molecule. Additionally, the proton conductivity of the SPH-Im composite material increased with the mixing of the Im molecule and reached a maximum proton conductivity at $R=0.2$. This proton conductivity was $4.4 \times 10^{-4} \mathrm{~S} \mathrm{~cm}^{-1}$ at $130{ }^{\circ} \mathrm{C}$ under flowing dry nitrogen. Furthermore, the $E_{\mathrm{a}}$ of the proton conduction in the SPH-Im composite material was $0.27-0.76 \mathrm{eV}$. These results suggested that the proton conductive mechanism in composite material was based on the anhydrous proton transfer from the $-\mathrm{COOH}$ group to the deprotonated $-\mathrm{COO}^{-}$group.
\end{abstract}

Keywords: Composite material, Soy protein, Anhydrous proton conduction, Polymer electrolyte, Acidic amino acid

\section{$\underline{\text { FULL TEXT }}$}

(C) 2021 The Authors. Published by ESG (www.electrochemsci.org). This article is an open access article distributed under the terms and conditions of the Creative Commons Attribution license (http://creativecommons.org/licenses/by/4.0/). 